\title{
Analisis pengaruh pertumbuhan ekonomi, indeks pembangunan manusia (IPM) dan upah minimum provinsi (UMP) terhadap kemiskinan di Kabupaten Merangin
}

\author{
Nadya Agustin*; M. Syurya Hidayat; Etik Umiyati \\ Prodi Ekonomi Pembangunan Fak.Ekonomi dan Bisnis Universitas Jambi \\ *E-mail korespodensi:nadyaagustin605@gmail.com
}

\begin{abstract}
This study aims to analyze: 1) The effect of economic growth, HDI, and Provincial minimum wage (PMW) on poverty levels in Merangin Regency. 2) The effect of economic growth, HDI, and PMW on the depth of poverty in Merangin Regency. 3) The effect of economic growth, HDI, and PMW on the severity of poverty in Merangin Regency. The data used are secondary data during the period 2002-2017. Data analysis tool using multiple linear regression method. Based on the results of the analysis, it is known that: 1) Simultaneously, economic growth, HDI, and PMW have a significant effect on the level, depth, and severity of poverty in Merangin Regency. 2) Partially economic growth has a significant effect on the level, depth, and severity of poverty in Merangin Regency, 3) HDI partially has a significant effect on the level, depth, and severity of poverty in Merangin Regency. 4) The PMW partially has a significant effect on the poverty level, but the PMW has no significant effect on the depth and severity of poverty in Merangin Regency.
\end{abstract}

Keywords: Poverty, Economic growth, HDI,Provincial minimum wage(PMW)

\begin{abstract}
Abstrak
Penelitian ini bertujuan untuk menganalisis : 1) Pengaruh pertumbuhan ekonomi, IPM dan UMP terhadap tingkat kemiskinan di Kabupaten Merangin. 2) Pengaruh pertumbuhan ekonomi, IPM dan UMP terhadap kedalaman kemiskinan di Kabupaten Merangin. 3) Pengaruh pertumbuhan ekonomi, IPM dan UMP terhadap keparahan kemiskinan di Kabupaten Merangin. Data yang digunakan adalah data sekunder selama periode tahun 2002-2017. Alat analisis data dengan menggunakan metode regresi linier berganda. Berdasarkan hasil analisis diketahui bahwa : 1) Secara simultan pertumbuhan ekonomi, IPM dan UMP berpengaruh signifikan terhadap tingkat, kedalaman dan keparahan kemiskinan di Kabupaten Merangin. 2) Pertumbuhan ekonomi secara parsial berpengaruh signifikan terhadap tingkat, kedalaman dan keparahan kemiskinan di Kabupaten Merangin, 3) IPM secara parsial berpengaruh signifikan terhadap tingkat, kedalaman dan keparahan kemiskinan di Kabupaten Merangin. 4) UMP secara parsial berpengaruh signifikan terhadap tingkat kemiskinan akan tetapi UMP tidak berpengaruh signifikan terhadap kedalaman dan keparahan kemiskinan di Kabupaten Merangin.
\end{abstract}

Kata kunci: Kemiskinan, Pertumbuhan ekonomi, IPM,Upah minimum provinsi (UMP)

\section{PENDAHULUAN}

Kemiskinan merupakan salah satu persoalan mendasar yang menjadi pusat perhatian pemerintah di negara manapun. Kemiskinan merupakan suatu keadaan yang 
sering dihubungkan dengan kebutuhan, kesulitan dan kekurangan di berbagai keadaan hidup. Menurut Rintuh dalam Romi (2018) kemiskinan dapat diartikan sebagai ketidakmampuan seseorang dalam memenuhi kebutuhan konsumsi dasar dan meningkatkan kebutuhan konsumsi dasar dan kualitas hidupnya.

Menurut World Bank (2004), salah satu penyebab kemiskinan adalah karena kurangnya pendapatan dan aset (lack of income and assets) untuk memenuhi kebutuhan dasar seperti makanan, pakaian, perumahan dan tingkat kesehatan dan pendidikan yang dapat diterima (acceptable). . Dalam arti poverty, kemiskinan dipahami sebagai keadaan kekurangan uang dan barang untuk menjamin kelangsungan hidup.

Sedangkan menurut Departemen Sosial dan Badan Pusat Statistik mendefinisikan kemiskinan dari perspektif kebutuhan dasar yaitu kemiskinan didefinisikan sebagai ketidakmampuan individu dalam memenuhi kebutuhan dasar minimal untuk hidup layak. Lebih jauh disebutkan kemiskinan merupakan sebuah kondisi yang berada dibawah garis nilai standar kebutuhan minimum, baik untuk makanan dan non-makanan yang disebut garis kemiskinan (poverty line) atau batas kemiskinan (poverty threshold). Dalam arti poverty, kemiskinan dipahami sebagai keadaan kekurangan uang dan barang untuk menjamin kelangsungan hidup.

Tujuan pembangunan nasional Negara Indonesia salah satunya sebagaimana diamanatkan dalam alinea keempat Pembukaan Undang-Undang Dasar 1945 yaitu untuk memajukan kesejahteraan umum. Kesejahteraan umum menurut Badan Pusat Statistik (2000) merupakan kondisi terpenuhinya kebutuhan material, spiritual, dan sosial penduduk negara agar dapat hidup layak dan mampu mengembangkan diri, sehingga dapat melaksanakan fungsi sosial dan ekonominya. Kesejahteraan umum di Indonesia dapat digambarkan salah satunya berdasarkan tingkat kemiskinan penduduk di Indonesia. Berbagai kegiatan pembangunan nasional dilakukan pemerintah untuk meningkatkan kesejahteraan umum. Salah satunya dengan mengarahkan berbagai kegiatan pembangunan ke daerah-daerah, khususnya pembangunan pada daerah yang relatif memiliki penduduk dengan tingkat kesejahteraan yang rendah sehingga pemerintah daerah sangat berperan penting dalam menanggulangi kemiskinan.

Kemiskinan merupakan salah satu tolak ukur kondisi sosial ekonomi dalam menilai keberhasilan pembangunan yang dilakukan pemerintah di suatu negara maupun daerah yang dapat dilihat dari tingkat kemiskinan, indeks kedalaman kemiskinan dan indeks keparahan kemiskinan.

Kabupaten Merangin merupakan salah satu Kabupaten yang ada di Provinsi Jambi yang menghadapi masalah kemiskinan. Dimana tingkat kemiskinan di Kabupaten Merangin pada tahun 2012-2016 terus mengalami peningkatan dan pada tahun 2017 mengalami penurunan. pada tahun 2012 tingkat kemiskinan sebesar 8,09, kemudian tahun 2013 sebesar 8,23, selanjutnya tahun 2014 sebesar 9,37, tahun 2015 sebesar 9,80, kemudian tahun 2016 sebesar 9,95 dan tahun 2017 sebesar 9,43.

Sedangkan kedalaman kemiskinan di Kabupaten Merangin bersifat berfluktiatif yaitu pada tahun 2012 sebesar 1,19, tahun 2013 meningkat menjadi 1,49, selanjutnya tahun 2014 menurun menjadi 1,39, kemudian tahun 2015 kembali meningkat menjadi 1,57, tahun 2016 kembali meningkat menjadi 1,77 dan tahun 2017 menurun menjadi 1,69 .

Kemudian keparahan kemiskinan di Kabupaten Merangin juga memiliki angka yang berfluktuatif dimana pada tahun 2012 yaitu sebesar 0,31, kemudian tahun 2013 meningkat sebesar 0,37, lalu tahun 2014 menurun menjadi 0,33, tahun 2015 kembali 
menurun menjadi 0,32, tahun 2016 meningkat menjadi 0,49 dan tahun 2017 kembali meningkat menjadi 0,52. Beberapa faktor yang dapat mempengaruhi kemiskinan di Kabupaten Merangin adalah pertumbuhan ekonomi, IPM dan UMP.

Salah satu sasaran pembangunan ekonomi daerah adalah meningkatkan laju pertumbuhan ekonomi daerah. Pertumbuhan ekonomi merupakan kunci dari penurunan kemiskinan di suatu wilayah. Dengan pertumbuhan ekonomi yang meningkat di masing-masing daerah mengartikan bahwa pemerintah mampu meningkatkan kesejahteraan masyarakatnya, sehingga dapat mengurangi tingkat kemiskinanHubungan antara pertumbuhan ekonomi atau peningkatan output dan kemiskinan menghasilkan suatu dasar kerangka pemikiran, yakni efek trickle-down dari pertumbuhan ekonomi dalam bentuk peningkatan kesempatan kerja atau pengurangan pengangguran dan peningkatan upah/pendapatan dari kelompok miskin (Aziz,2016). Menurut Murni (2013) pertumbuhan ekonomi adalah suatu kondisi dimana terjadinya perkembangan GNP yang mencerminkan adanya pertumbuhan output per kapita dan meningkatnya standar hidup masyarakat.

Kualitas sumber daya manusia juga dapat menjadi faktor penyebab terjadinya penduduk miskin. Kualitas sumber daya manusia dapat dilihat dari indeks kualitas hidup atau biasa disebut Indeks Pembangunan Manusia (IPM). Indeks pembangunan manusia merupakan salah satu alat ukur yang dapat digunakan untuk menilai kualitas pembangunan manusia, baik dari sisi dampaknya terhadap kondisi fisik manusia (kesehatan dan kesejahteraan) maupun yang bersifat non-fisik (intelektualitas). Pembangunan yang berdampak pada kondisi fisik masyarakat tercermin dalam angka harapan hidup serta kemampuan daya beli, sedangkan dampak non-fisik dilihat dari kualitas pendidikan masyarakat (Susanti, 2013). Indeks Pembangunan Manusia (IPM) diperkenalkan oleh United Nations Development Programme (UNDP) pada tahun 1990 dan dipublikasikan secara berkala dalam laporan tahunan. IPM dibentuk oleh tiga dimensi dasar, yaitu diantaranya umur panjang, pengetahuan, dan standar hidup layak. IPM merupakan ukuran untuk melihat dampak kinerja pembangunan wilayah, karena memperlihatkan kualitas penduduk suatu wilayah dalam hal harapan hidup, intelektualitas dan standar hidup layakSaat perencanaan pembangunan, IPM juga berfungsi memberikan tuntunan menentukan prioritas dalam merumuskan suatu kebijakan. IPM yang merupakan alat ukur bagi kualitas pembangunan manusia, menjadi variabel penting bagi suatu negara dalam menentaskan kemiskinan.

Kebijakan upah minimum juga berpengaruh terhadap tingkat kemiskinan. Menurut Sonny Sumarsono dalam Khabibi (2013) gagasan upah minimum yang sudah dimulai dan dikembangkan sejak awal tahun 1970-an bertujuan untuk mengusahakan agar dalam jangka panjang besarnya upah minimum paling sedikit dapat memenuhi kebutuhan hidup minimum (KHM), sehingga diharapkan dapat menjamin tenaga kerja untuk memenuhi kebutuhan hidup beserta keluarga dan sekaligus dapat mendorong peningkatan produktivitas kerja dan kesejahteraan buruh. Menurut Undang-Undang No. 13 Tahun 2003 dan kemudian diperbaharui pada 23 Oktober 2015 Tentang Ketenagakerjaan dan Kebijakan Pengupahan, menyebutkan bahwa peninjauan besarnya upah minimum provinsi dan upah minimum kabupaten /kota diadakan satu tahun sekali. Dalam mendorong peningkatan pekerja dalam pelaksanaan proses produksi serta peningkatan kesejahteraan pekerja yang salah satunya adalah melalui mekanisme penetapan Upah Minumum Kabupaten/Provinsi. Dan dalam pelaksanaannya harus memperhatikan kondisi daerah, kemampuan perusahaan yang mengacu pada kebutuhan 
hidup layak (Andriyani, 2017). Tingkat upah minimum Provinsi dijadikan sebagai dasar dalam penetapan upah minimum Kota/Kabupaten yang yang ada di Provinsi Jambi.

Beberapa faktor yang mempengarui kemiskinan sebelumnya pernah dibahas oleh Woyanti (2013) dengan hasil penelitian menyatakan bahwa kemiskinan secara signifikan dipengaruhi oleh pertumbuhan ekonomi dan upah. Penelitian berikutnya yang dilakukan oleh Islami (2016) dengan hasil penelitian tingkat kemiskinan secara signifikan dipengaruhi oleh IPM dan UMP dan penelitian yang dilakukan oleh Yulianti (2016) dengan hasil penelitian kemiskinan dipengaruhi oleh IPM dan UMP. Tujuan penelitian ini untuk mengetahui dan menganalisis; 1) Pengaruh pertumbuhan ekonomi, IPM dan UMP terhadap tingkat kemiskinan di Kabupaten Merangin. 2) Pengaruh pertumbuhan ekonomi, IPM dan UMP terhadap kedalaman kemiskinan di Kabupaten Merangin. 3) Pengaruh pertumbuhan ekonomi, IPM dan UMP terhadap keparahan kemiskinan di Kabupaten Merangin.

\section{METODE}

Jenis data yang digunakan dalam penelitian ini adalah data sekunder runtut waktu (time series) selama 16 tahun dari tahun 2002-2017 yang meliputi; a) Tingkat kemiskinan Kabupaten Merangin; b) Kedalaman kemiskinan Kabupaten Merangin; c) Keparahan kemiskinan Kabupaten Merangin ; Pertumbuhan ekonomi Kabupaten Merangin; e) IPM Kabupaten Merangin; f) UMP Jambi . Penelitian ini menggunakan metode analisis kuantitatif. Untuk menganalisis pengaruh pertumbuhan ekonomi, IPM dan UMP terhadap tingkat kemiskinan, kedalaman kemiskinan dan keparahan kemiskinan digunakan alat analisis regresi linier berganda.

Untuk menganalisis faktor-faktor yang mempengaruhi tingkat kemiskinan maka digunakan rumus sebagai berikut (McClave dkk, 2011) :

$\mathbf{Y}_{1}=\beta_{0}+\beta_{1} X_{1}+\beta_{2} X_{2}+\beta_{3} X_{3}+e i$

Untuk menganalisis faktor-faktor yang mempengaruhi tingkat kedalaman kemiskinan maka digunakan rumus sebagai berikut :

$\mathbf{Y}_{2}=\beta_{0}+\beta_{1} X_{1}+\beta_{2} X_{2}+\beta_{3} X_{3}+e i$

Untuk menganalisis faktor-faktor yang mempengaruhi tingkat keparahan kemiskinan maka digunakan rumus sebagai berikut :

$\mathbf{Y}_{3}=\beta_{0}+\beta_{1} X_{1}+\beta_{2} X_{2}+\beta_{3} X_{3}+e i$

Dimana :

$\mathrm{Y}_{1} \quad$ :Tingkat kemiskinan di Kabupaten Merangin

$\mathrm{Y}_{2} \quad$ :Tingkat kedalaman kemiskinan di Kabupaten Merangin

$\mathrm{Y}_{3} \quad$ : Tingkat keparahan kimiskinan di Kabupaten Merangin

$\beta_{0} \quad$ : Konstanta

$\beta_{1}, \beta_{2}, \beta_{3}:$ Koefisien regresi

$\mathrm{X}_{1} \quad$ : Pertumbuhan ekonomi Kabupaten Merangin

$\mathrm{X}_{2} \quad$ : IPM Kabupaten Merangin

$\mathrm{X}_{3} \quad$ : UMP Jambi

e : error

Setelah dilakukan perhitungan dengan menggunakan alat analisis regresi linier berganda, maka dilakukan pengujian hipotesis yaitu yang uji $\mathrm{F}$, uji t dan koefisien determinasi. Selanjutnya pengujian asumsi klasik menjadi suatu hal yang penting untuk 
melihat penyimpangan-penyimpangan yang terjadi pada suatu model, maka pada penelitian ini dilakukan pengujian asumsi klasik yaitu uji multikolinearitas. Uji autokorelasi menggunakan uji LM dan uji heterokedastisitas menggunakan uji white. (Junaidi, 2015).

\section{HASIL DAN PEMBAHASAN}

\section{Perkembangan kemiskinan Kabupaten Merangin}

Kemiskinan merupakan sebuah kondisi seseorang yang berada dibawah garis nilai standar kebutuhan minimum, baik untuk makanan dan non-makanan yang disebut garis kemiskinan (poverty line) atau batas kemiskinan (poverty threshold). Kemiskinan dapat dilihat dari tingkat kemiskinan, tingkat kedalaman kemiskinan dan tingkat keparahan kemiskinan di Kabupaten Merangin pada tahun 2002 hingga tahun 2017. Perkembangan kemiskinan dapat dijelaskan pada penyajian tabel 1 sebagai berikut :

Tabel 1. Jumlah penduduk miskin, tingkat kemiskinan, tingkat kedalaman kemiskinan dan tingkat keparahan kemiskinan di Kabupaten Merangin tahun 2002-2017

\begin{tabular}{ccccc}
\hline Tahun & $\begin{array}{c}\text { Jumlah Penduduk } \\
\text { Miskin }\end{array}$ & $\begin{array}{c}\text { Tingkat } \\
\text { Kemiskinan }\end{array}$ & $\begin{array}{c}\text { Kedalaman } \\
\text { Kemiskinan }\end{array}$ & $\begin{array}{c}\text { Keparahan } \\
\text { Kemiskinan }\end{array}$ \\
\hline 2002 & 42.100 & 16,04 & 2,55 & 0,54 \\
2003 & 39.900 & 14,75 & 2,16 & 0,52 \\
2004 & 41.300 & 15.00 & 2,09 & 0,5 \\
2005 & 41.300 & 14,73 & 2,14 & 0,53 \\
2006 & 38.900 & 14,05 & 2,30 & 0,53 \\
2007 & 34.200 & 12,10 & 1,63 & 0,34 \\
2008 & 27.500 & 9,50 & 1,84 & 0,47 \\
2009 & 25.500 & 8,65 & 1,16 & 0,26 \\
2010 & 27.300 & 8,07 & 0,85 & 0,13 \\
2011 & 28.400 & 7,68 & 0,92 & 0,19 \\
2012 & 28.200 & 8,09 & 1,19 & 0,31 \\
2013 & 33.130 & 8,23 & 1,49 & 0,37 \\
2014 & 33.900 & 9,37 & 1,39 & 0,33 \\
2015 & 35.770 & 9,80 & 1,57 & 0,32 \\
2016 & 36.890 & 9,95 & 1,77 & 0,49 \\
2017 & 35.480 & 9,43 & 1,69 & 0,52 \\
\hline Rata-rata & $\mathbf{3 4 . 3 6 1}$ & $\mathbf{1 0 , 9 6}$ & $\mathbf{1 , 6 7}$ & $\mathbf{0 , 4 0}$ \\
\hline
\end{tabular}

Sumber: BPS Provinsi Jambi, 2019

Dari Tabel 1, terlihat dalam rentang waktu 2002 sampai dengan tahun 2017 jumlah penduduk miskin Kabupaten Merangin pada tahun 2002 hingga 2017 mengalami angka yang berfluktuatif dengan rata-rata 34.361 jiwa. Selanjutnya rata-rata tingkat kemiskinan di Kabupaten Merangin adaah 10,96. Kemudian rata-rata kedalaman kemiskinan di Kabupaten Merangin adaah sebesar 1,67 dan keparahan kemiskinan di Kabupaten Merangin adaah sebesar 0,40.

\section{Perkembangan pertumbuhan ekonomi Kabupaten Merangin}

Pertumbuhan ekonomi merupakan suatu gambaran mengenai dampak kebijakan pembangunan yang dilaksanakan, khususnya dalam bidang ekonomi. Laju pertumbuhan ekonomi dapat dilihat dari PDRB atas dasar harga konstan, pertumbuhan yang positif merupakan indikator adanya peningkatan perekonomian suatu daerah, sebaliknya apabila negatif menunjukan penurunan perekonomian suatu daerah. 
Tabel 2. Pertumbuhan ekonomi ADHK Kabupaten Merangin Tahun 2002-2017

\begin{tabular}{cc}
\hline Tahun & Pertumbuhan Ekonomi \\
\hline 2002 & 3,70 \\
2003 & 4,07 \\
2004 & 4,85 \\
2005 & 5,19 \\
2006 & 5,99 \\
2007 & 7,02 \\
2008 & 5,99 \\
2009 & 8,42 \\
2010 & 7,85 \\
2011 & 7,02 \\
2012 & 6,37 \\
2013 & 6,45 \\
2014 & 7,13 \\
2015 & 5,48 \\
2016 & 6,21 \\
2017 & 5,55 \\
\hline Rata-rata & $\mathbf{6 , 0 8}$
\end{tabular}

Sumber : BPS Provinsi Jambi, 2019

Berdasarkan Tabel 2, Rata-rata pertumbuhan ekonomi Kabupaten Merangin pada 2002 hingga tahun 2017 yaitu sebesar 6,08 persen. Pertumbuhan ekonomi tertinggi dicapai pada tahun 2009 dengan angka sebesar 8,42 persen. Hal ini menunjukkan perekonomian Kabupaten Merangin sedang dalam kondisi baik. Adapun sumber utama yang memberikan kontribusi terhadap pertumbuhan ekonomi Kabupaten Merangin adalah sektor Pertanian, Perkebunan, Peternakan, Kehutanan dan Perikanan. Pertumbuhan ekonomi terendah dicapai pada tahun 2002 yaitu dengan angka sebesar 3,70 persen. Hal ini menunjukan terjadi suatu perlambatan kondisi perekonomian Kabupaten Merangin.

\section{Perkembangan IPM Kabupaten Merangin}

Indeks Pembangunan Manusia (IPM) menurut Badan Pusat Statistik (BPS) merupakan indikator komposit tunggal yang digunakan untuk mengukur pencapaian pembangunan manusia yang telah dilakukan di suatu wilayah karena mampu mengukur dimensi pokok pembangunan manusia yang dinilai mampu mencerminkan status kemampuan dasar penduduk.

Bersadarkan Tabel 3, indeks pembangunan manusia (IPM) kabupaten merangin dalam periode tahun 2002 hingga tahun 2017 cenderung mengalami peningkatan. Dimana IPM kabupaten merangin tahun 2002 hingga tahun 2009 terus mengalami peningkatan, kemudian tahun 2010 IPM mengalami penurunan dan selanjutnya IPM tahun 2011 hingga tahun 2017 kembali mengalami peningkatan. Rata-rata IPM Kabupaten Merangin yaitu sebesar 67,89 persen.

Tinggi rendahnya tingkat IPM tidak bisa dilepaskan dari peran pemerintah. Pemerintah memiliki peran yang penting dalam mewujudkan pembangunan ekonomi melalui kebijakan fiskalnya. Diantara instrumen kebijakan fiskal tersebut adalah instrumen pengalokasian dana atau anggaran yang dikeluarkan pemerintah untuk fasilitas publik seperti kesehatan dan pendidikan, dimana anggaran yang dikeluarkan pemerintah untuk pendidikan pada tahun 2017 adalah sebesar 336.671.601.825,49 rupiah dan untuk kesehatan adalah sebesar 169.434.979.869,12 rupiah. Pengeluaran pemerintah di bidang kesehatan dan pendidikan diharapkan mampu untuk 
meningkatkan angka harapan hidup maupun menurunkan angka kematian ibu hamil dan kematian bayi sebagai suatu komponen dalam pembangunan manusia dan dapat meningkatkan kualitas sumberdaya manusia melalui tingkat pendidikan.

Tabel 3. Indeks pembangunan manusia (IPM) Kabupaten Merangin tahun 2012-2017

\begin{tabular}{cc}
\hline Tahun & Indeks pembangunan manusia (IPM) \\
\hline 2002 & 66,30 \\
2003 & 67,64 \\
2004 & 69,30 \\
2005 & 69,90 \\
2006 & 70,30 \\
2007 & 70,70 \\
2008 & 71,39 \\
2009 & 71,63 \\
2010 & 63,85 \\
2011 & 64,40 \\
2012 & 65,31 \\
2013 & 65,82 \\
2014 & 66,21 \\
2015 & 67,40 \\
2016 & 67,86 \\
2017 & 68,30 \\
\hline Rata-rata & $\mathbf{6 7 , 8 9}$
\end{tabular}

Sumber : BPS Provinsi Jambi, 2019

\section{Perkembangan upah minimum provinsi (UMP) Jambi}

UMP menjadi sesuatu hal yang penting baik bagi untuk tenaga kerja maupun bagi pemerintah, karena hal ini akan menyangkut pada kesejahteraan tenaga kerja itu sendiri. Dalam menetapkan besarnya upah tenaga kerja, perusahaan dilarang membayar lebih rendah dari ketentuan upah minimum yang telah ditetapkan pemerintah setempat.

Tabel 4. Upah Minimum Provinsi Jambi (UMP) tahun 2002-2017

\begin{tabular}{ccc}
\hline Tahun & UMP (Rupiah) & Perkembangan (Persen) \\
\hline 2002 & 304.000 & 24,08 \\
2003 & 390.000 & 28,29 \\
2004 & 425.000 & 8,97 \\
2005 & 485.000 & 14,12 \\
2006 & 563.000 & 16,08 \\
2007 & 658.000 & 16,87 \\
2008 & 724.000 & 10,03 \\
2009 & 800.000 & 10,5 \\
2010 & 900.000 & 12,5 \\
2011 & 1.028 .000 & 14,22 \\
2012 & 1.142 .500 & 11,14 \\
2013 & 1.300 .000 & 13,79 \\
2014 & 1.502 .300 & 15,56 \\
2015 & 1.710 .000 & 13,83 \\
2016 & 1.906 .650 & 11,5 \\
2017 & 2.063 .948 & 8,25 \\
\hline
\end{tabular}

Sumber : BPS Provinsi Jambi tahun, 2019 


\section{Faktor-faktor yang mempengaruhi tingkat kemiskinan Kabupaten Merangin}

Analisis faktor-faktor yang mempengaruhi tingkat kemiskinan tahun 2002-2017 di Kabupaten Merangin dapat diketahui dengan menggunakan alat analisis model regresi linear berganda. Hasil perhitungan dari model regresi tersebut dapat dijelaskan pada penyajian tabel 5 sebagai berikut:

Tabel 5. Hasil regresi berganda

\begin{tabular}{ccccc}
\hline Variable & Coefficient & Std Error & t statistic & Prob \\
\hline $\mathrm{C}$ & 3.890746 & 10.32789 & 0.376722 & 0.7130 \\
$\mathrm{X}_{1}$ & -1.468868 & 0.286634 & -5.124543 & 0.0003 \\
$\mathrm{X}_{2}$ & 0.267651 & 0.148213 & 1.805863 & 0.0961 \\
$\mathrm{X}_{3}$ & -0.002179 & 0.000679 & -3.211279 & 0.0075 \\
\hline $\mathrm{R}^{2}=0.831006$ & & & & \\
$\mathrm{~F}=19.66952$ & & & \\
Prob (F-statistik) $=0.000063$ & & & \\
Sumber: Data diolah, 2019 &
\end{tabular}

Berdasarkan persamaan tabel 5 menunjukkan bahwa nilai probabilitas $\mathrm{F}$ statistik yaitu 0,000063 yang nilainya lebih kecil dibandingkan dengan nilai taraf signifikansi 10 persen, sehingga $\mathrm{H}_{0}$ ditolak dan $\mathrm{Ha}$ diterima. Ini berarti secara bersama-sama pertumbuhan ekonomi, IPM dan UMP berpengaruh signifikan terhadap tingkat kemiskinan. Secara parsial, nilai probabilitas variabel pertumbuhan ekonomi adalah 0,0003 lebih kecil dibandingkan taraf signifikansi 10 persen, sehingga $\mathrm{H}_{0}$ ditolak dan $\mathrm{Ha}$ diterima. Ini berarti secara parsial pertumbuhan ekonomi berpengaruh signifikan terhadap tingkat kemiskinan.Variabel IPM didapatkan nilai probabilitas sebesar 0,0961 yang nilainya lebih kecil dibandingkan dengan nilai taraf signifikansi 10 persen sehingga $\mathrm{H}_{0}$ ditolak dan Ha diterima. Ini berarti secara parsial variabel IPM berpengaruh signifikan terhadap tingkat kemiskinan. Variabel UMP didapatkan nilai probabilitasnya adalah 0,0075 yang nilainya lebih kecil dibandingkan taraf signifikansi 10 persen, sehingga $\mathrm{H}_{0}$ ditolak dan $\mathrm{Ha}$ diterima. Ini berarti secara parsial UMP berpengaruh signfikan tingkat kemiskinan. Nilai koefisien determinasi yaitu 0,831006 artinya model ini dapat menjelaskan pengaruh variabel-variabel bebas (Pertumbuhan ekonomi, IPM dan UMP) terhadap tingkat kemiskinan sebesar 83,11 persen dan sisanya yaitu 16,89 persen di pengaruhi oleh variabel-variabel lainnya.

\section{Faktor-faktor yang mempengaruhi kedalaman kemiskinan Kabupaten Merangin}

Analisis faktor-faktor yang mempengaruhi kedalaman kemiskinan tahun 20022017 di Kabupaten Merangin dapat diketahui dengan menggunakan alat analisis model regresi linear berganda.

Berdasarkan Tabel 6 menunjukkan bahwa nilai probabilitas $\mathrm{F}$ statistik yaitu 0,000013 yang nilainya lebih kecil dibandingkan dengan nilai taraf signifikansi 10 persen, sehingga $\mathrm{H}_{0}$ ditolak dan $\mathrm{Ha}$ diterima. Ini berarti secara bersama-sama pertumbuhan ekonomi, IPM dan UMP berpengaruh signifikan terhadap kedalaman kemiskinan. Secara parsial, nilai probabilitas variabel pertumbuhan ekonomi adalah 0,0000 lebih kecil dibandingkan taraf signifikansi 10 persen, sehingga $\mathrm{H}_{0}$ ditolak dan $\mathrm{Ha}$ diterima. Ini berarti secara parsial pertumbuhan ekonomi berpengaruh signifikan terhadap kedalaman kemiskinan.Variabel IPM didapatkan nilai probabilitas sebesar 
0,0040 yang nilainya lebih kecil dibandingkan dengan nilai taraf signifikansi 10 persen sehingga $\mathrm{H}_{0}$ ditolak dan Ha diterima. Ini berarti secara parsial variabel IPM berpengaruh signifikan terhadap kedalaman kemiskinan. Variabel UMP didapatkan nilai probabilitasnya adalah 0,4139 yang nilainya lebih besar dibandingkan taraf signifikansi 10 persen, sehingga $\mathrm{H}_{0}$ diterima dan $\mathrm{Ha}$ ditolak. Ini berarti secara parsial UMP tidak berpengaruh signfikan terhadap kedalaman kemiskinan. Nilai koefisien determinasi yaitu 0,870342 artinya model ini dapat menjelaskan pengaruh variabel-variabel bebas (Pertumbuhan ekonomi, IPM dan UMP) terhadap kedalaman kemiskinan sebesar 87,03 persen dan sisanya yaitu 12,97 persen di pengaruhi oleh variabel-variabel lainnya. Hasil perhitungan dari model regresi tersebut dapat dijelaskan pada penyajian tabel 2 sebagai berikut:

Tabel 6. Hasil regresi berganda

\begin{tabular}{ccccc}
\hline Variable & Coefficient & Std Error & t statistic & Prob \\
\hline $\mathrm{C}$ & -1.632604 & 1.519154 & -1.074680 & 0.3037 \\
$\mathrm{X}_{1}$ & -0.307733 & 0.042162 & -7.298887 & 0.0000 \\
$\mathrm{X}_{2}$ & 0.077459 & 0.021801 & 3.553020 & 0.0040 \\
$\mathrm{X}_{3}$ & $-8.45 \mathrm{E}-05$ & $9.98 \mathrm{E}-05$ & -0.846373 & 0.4139 \\
\hline $\mathrm{R}^{2}=0.870342$ & & & & \\
$\mathrm{~F}=26.85039$ & & & \\
Prob (F-statistik) $=0.000013$ & &
\end{tabular}

Faktor-faktor yang mempengaruhi keparahan kemiskinan Kabupaten Merangin

Analisis faktor-faktor yang mempengaruhi keparahan kemiskinan tahun 20022017 di Kabupaten Merangin dapat diketahui dengan menggunakan alat analisis model regresi linear berganda. Hasil perhitungan dari model regresi tersebut dapat dijelaskan pada penyajian Tabel 7 sebagai berikut:

Tabel 7. Hasil regresi berganda

\begin{tabular}{ccccc}
\hline Variable & Coefficient & Std Error & t statistic & Prob \\
\hline $\mathrm{C}$ & -0.921912 & 0.447694 & -2.059244 & 0.0619 \\
$\mathrm{X}_{1}$ & -0.085251 & 0.012425 & -6.861268 & 0.0000 \\
$\mathrm{X}_{2}$ & 0.026436 & 0.006425 & 4.114710 & 0.0014 \\
$\mathrm{X}_{3}$ & $4.26 \mathrm{E}-05$ & $2.94 \mathrm{E}-05$ & 1.447319 & 0.1734 \\
\hline $\mathrm{R}^{2}=0.843279$ & & & & \\
$\mathrm{~F}=21.52301$ & & & & \\
Prob (F-statistik) $=0.000040$ & & & \\
\hline
\end{tabular}

Sumber: Data diolah, 2019

Berdasarkan persamaan Tabel 7 menunjukkan bahwa nilai probabilitas F statistik yaitu 0,000040 yang nilainya lebih kecil dibandingkan dengan nilai taraf signifikansi 10 persen, sehingga $\mathrm{H}_{0}$ ditolak dan $\mathrm{Ha}$ diterima. Ini berarti secara bersama-sama pertumbuhan ekonomi, IPM dan UMP berpengaruh signifikan terhadap keparahan kemiskinan. Secara parsial, nilai probabilitas variabel pertumbuhan ekonomi adalah 
0,0000 lebih kecil dibandingkan taraf signifikansi 10 persen, sehingga $\mathrm{H}_{0}$ ditolak dan $\mathrm{Ha}$ diterima. Ini berarti secara parsial pertumbuhan ekonomi berpengaruh signifikan terhadap kedalaman kemiskinan.Variabel IPM didapatkan nilai probabilitas sebesar 0,0014 yang nilainya lebih kecil dibandingkan dengan nilai taraf signifikansi 10 persen sehingga $\mathrm{H}_{0}$ ditolak dan Ha diterima. Ini berarti secara parsial variabel IPM berpengaruh signifikan terhadap keparahan kemiskinan. Variabel UMP didapatkan nilai probabilitasnya adalah 0,1734 yang nilainya lebih besar dibandingkan taraf signifikansi 10 persen, sehingga $\mathrm{H}_{0}$ diterima dan Ha ditolak. Ini berarti secara parsial UMP tidak berpengaruh signfikan terhadap keparahan kemiskinan. Nilai koefisien determinasi yaitu 0,843279 artinya model ini dapat menjelaskan pengaruh variabel-variabel bebas (Pertumbuhan ekonomi, IPM dan UMP) terhadap keparahan kemiskinan sebesar 84,33 persen dan sisanya yaitu 15,67 persen di pengaruhi oleh variabel-variabel lainnya.

Pengujian asumsi klasik yang telah dilakukan pada ketiga model regresi linier berganda yaitu uji multikolinearitas dengan melihat nilai VIF dan TOL, dari ketiga variabel bebas yaitu pertumbuhan ekonomi, IPM dan UMP nilai VIF lebih kecil dari angka 10, maka tidak ada multikolinearitas di dalam model regresi ini. Demikian pula dengan TOL, nilai TOL tidak mendekati angka 0 sehingga dapat disimpulkan tidak ada multikolinearitas dalam model. Selanjutnya uji autokorelasi yaitu uji LM dengan membandingkan nilai probabilitas Obs*R-squared dengan taraf signifikan 5 persen. Setelah dibandingkan didapatkan probabilitas chi square yang nilai nya lebih besar dibandingkan signifikansi 5 persen, sehingga dapat disimpulkan model tidak mengandung autokorelasi. Kemudian uji Heterokedastisitas yaitu menggunakan uji white maka didapatkan nilai probabilitas chi square yang nilai nya lebih besar dibandingkan signifikansi 5 persen, sehingga dapat disimpulkan model tidak mengandung heterokedastisitas.

\section{KESIMPULAN DAN SARAN}

\section{Kesimpulan}

Selama tahun 2002-2017 rata-rata tingkat kemiskinan Kabupaten Merangin yaitu sebesar 10,96 persen, kedalaman kemiskinan sebesar 1,67 persen dan keparahan kemiskinan sebesar 0,39 persen. Secara simultan pertumbuhan ekonomi, IPM dan UMP berpengaruh signifikan terhadap tingkat kemiskinan, kedalaman kemiskinan dan keparahan kemiskinan di Kabupaten Merangin. Pertumbuhan ekonomi secara parsial berpengaruh signifikan terhadap tingkat kemiskinan, kedalaman kemiskinan dan keparahan kemiskinan di Kabupaten Merangin. IPM secara parsial berpengaruh signifikan terhadap tingkat kemiskinan, kedalaman kemiskinan dan keparahan kemiskinan di Kabupaten Merangin. UMP secara parsial berpengaruh signifikan terhadap tingkat kemiskinan, akan tetapi UMP tidak berpengaruh signifikan terhadap kedalaman kemiskinan dan keparahan kemiskinan di Kabupaten Merangin.

\section{Saran}

Hendaknya pemerintah Kabupaten Merangin lebih mengoptimalkan pembangunan sektoral yang berorientasi pada peningkatan kualitas dan kuantitas produksi dengan memanfatkan segala potensi yang dimiliki termasuk kekayaan sumber daya manusia, sumber daya alam dan investasi sehingga dapat mendorong peningkatan PDRB yang pada akhirnya dapat memacu laju pertumbuhan ekonomi. Dalam 
meningkatkan IPM diharapkan pemerintah memperbaiki program peningkatan pendidikan masyarakat yang dapat dilakukan dengan memudahkan akses terhadap fasilitas pendidikan dari tingkat dasar sampai tingkat lanjutan agar partisipasi penduduk usia sekolah dapat terjamin. Selain itu, diperlukan bantuan agar masyarakat dapat menikmati sekolah tanpa mengeluarkan biaya yang besar dari pendidikan dasar sampai pendidikan lanjutan. kemudian, untuk kesehatan diharapkan pemerintah dapat mempermudah akses masyarakat ke fasilitas kesehatan dan perlu ditingkatkan lagi pembangunan infrastruktur baik berupa fasilitas kesehatannya maupun akses jalan dan pembiayaannya. Dalam penetapan besaran upah minimum provinsi, pemerintah harus juga memperhitungkan harga barang-barang kebutuhan masyarakat, sehingga upah yang ditetapkan sesuai dengan kebutuhan.

\section{DAFTAR PUSTAKA}

Aziz, Gamal Abdul, Eny Rochaida, Warsilan. (2016). Faktor-faktor yang mempengaruhi kemiskinan di Kabupaten Kutai Kartanegara. Jurnal Ekonomi Keuangan dan Manajemen. Vol. 12 (1).

D Chandra, S Hidayat, R Rosmeli.(2017). Dampak dana perimbangan terhadap pertumbuhan ekonomi dan ketimpangan antar daerah di Provinsi Jambi, Jurnal Paradigma Ekonomika 12 (2), 67-76

Islami, Amalia. (2016). Analisis pengaruh Produk Domestik Regional Bruto (PDRB), Indeks Pembangunan Manusia (IPM) dan Upah Minimum Provinsi (UMP) terhadap tingkat kemiskinan periode 2005-2014 (studi kasus 10 Provinsi dengan tingkat kemiskinan tertinggi di Indonesia). Skripsi Fakultas Ekonomi dan Bisnis. Universitas Negeri Sunan Kalijaga: Yogyakarta.

Junaidi. (2015). Buku Ajar Ekonometrika 1. Penerbit Fakultas Ekonomi dan Bisnis. Universitas Jambi: Jambi.

Khabhibi, Achmad. (2013). Analisis faktor-faktor yang mempengaruhi tingkat kemiskinan (studi kasus 35 Kabupaten/Kota di Provinsi Jawa Tengah tahun 2011). Skripsi Fakultas Ekonomi. Universitas Sebelas Maret: Surakarta.

M Latif, S Syaparuddin, E Achmad.(2017).Hubungan belanja daerah, PMDN, PMA, tenaga kerja dan pertumbuhan ekonomi Provinsi Jambi (Pendekatan Kausalitas Granger), e-Jurnal Perspektif Ekonomi dan Pembangunan Daerah 6 (2), 85-96

McClave dkk. 2011. Statistik untuk Bisnis dan Ekonomi. penerbit Erlangga: Jakarta.

Murni, Asfia. (2013). Ekonomika Makro. Edisi Revisi. PT refika Aditama: Bandung.

Romi, Syahrur, Etik Umiyati. (2018). Pengaruh pertumbuhan ekonomi dan upah minimum terhadap kemiskinan di Kota Jambi. E-Jurnal Perspektif Ekonomi dan Pembangunan Daerah. 7 (1), 1-7

Saputra, Whisnu Adhi. (2011). Analisis pengaruh jumlah penduduk, PDRB, IPM, pengangguran terhadap tingkat kemiskinan di Kabupaten/Kota Jawa Tengah. Skripsi Fakultas Ekonomi. Universitas Diponegoro: Semarang.

Susanti, Sussy. (2013). Pengaruh produk domestik regional bruto, pengangguran dan indeks pembangunan manusia terhadap kemiskinan di Jawa Barat dengan menggunakan analisis data panel. Jurnal Matematika Integratif. 9 (1). 1-18

Woyanti, Nenik. (2013). Pengaruh pertumbuhan ekonomi dan UMP terhadap kemiskinan di Jawatengah pra dan pasca desentralisasi fiskal. jurnal media Ekonomi Dan Manajemen. 28. (2), 28-43 
Yudha, Okta Ryan Pranata. (2013). Pengaruh pertumbuhan ekonomi, upah minimum, tingkat pengangguran terbuka dan inflasi terhadap kemiskinan di Indonesia Tahun 2009-2011. Skripsi Fakultas Ekonomi. Universitas Negeri Semarang: Semarang.

Yulianti, Desi. (2016). Pengaruh indeks pembangunan manusia, pertumbuhan ekonomi, pengangguran dan upah terhadap kemiskinan di Provinsi DIY Periode Tahun 2007-2013. Skripsi Fakultas Ekonomi dan Bisnis Islam. Universitas Islam Negeri Sunan Kalijaga: Yogyakarta. 